\title{
The Influence of a Selected External Carbon Source on the Share of COD Fractions and the Speed of Denitrification Processes
}

\author{
Katarzyna Ignatowicz ${ }^{1 *}$, Joanna Smyk ${ }^{2}$ \\ 1 Faculty of Civil and Environmental Science, Bialystok University of Technology, ul. Wiejska 45A, Bialystok, \\ 15-351, Poland \\ 2 Transition Technologies Managed Services Sp. z o.o. \\ * Corresponding author's e-mail: k.ignatowicz@pb.edu.pl
}

\begin{abstract}
The article presents the effectiveness of the N, P, C (nitrogen, phosphorus and carbon) removal from sewage with the use of molasses as an external carbon source (ECS). The research was carried out during the wastewater treatment processes in two SBR-type activated sludge reactors. A cycle of the SBR operation lasted 360 minutes and included the following phases: wastewater supply ( $2 \mathrm{~min})$, anaerobic (60 $\mathrm{min})$, aeration (210 $\mathrm{min})$, sedimentation (60 min) and decantation (30 min). After twenty minutes of the wastewater supply, molasses was added to one of the reactors in the cycle, as a source of easily available organic compounds. The conducted tests showed that the use of molasses as an ECS during wastewater treatment resulted in higher nitrogen removal efficiency in comparison with the reactor without ECS. The wastewater treatment in the SBR without the addition of ECS resulted in a total nitrogen removal of $80 \%$ and ammonium nitrogen of $95.9 \%$, whereas the wastewater treatment in the reactor with the addition of molasses resulted in the removal of total nitrogen at $90.3 \%$ and ammonium nitrogen at $97.3 \%$. Despite the increase in the final nitrate concentration in both SBRs, the nitrate concentration in the reactor using an external carbon source was lower by as much as $4.5 \mathrm{mg} \mathrm{N} / \mathrm{dm}^{3}$. The COD fractions and their changes in wastewater were determined in order to find out their quantitative and percentage share. Determination of the COD fraction allows assessing the susceptibility of wastewater to biological treatment, additionally indicating the impurities that are difficult to decompose, which reduce the effectiveness of biological wastewater treatment. Introduction of

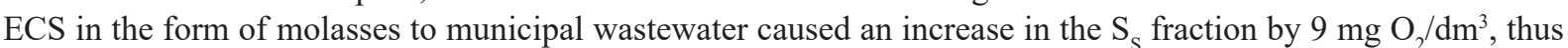
increasing the percentage of the readily biodegradable dissolved organic compounds by about $10 \%$. The increased amount of easily available carbon compounds has contributed to the increase of the denitrification rate. In the initial phase of denitrification with the addition of ECS in the form of molasses, an acceleration in the removal of nitrogen compounds by $2.48 \mathrm{mg} \mathrm{N} \cdot \mathrm{dm}^{3} / \mathrm{h}$ compared to the control reactor, was observed.
\end{abstract}

Keywords: external carbon source (ECS), molasses, SBR, WWTP

\section{INTRODUCTION}

The supply of an external source of carbon to the treated wastewater is often necessary to achieve a high efficiency of the wastewater treatment plant, which must meet very strict requirements for reducing the nitrogen concentrations. The use of conventional sources of coal results in high operating costs for wastewater treatment plants. The costs of an external coal source and waste management together account for more than $50 \%$ of the total cost of wastewater treatment
(Fernández-Nava et al. 2010, Bernat et al. 2016, Cherchi et al. 2009, Ignatowicz et al. 2011). Additionally, a period of adaptation of microorganisms is often required after the introduction of a given coal source to the wastewater treatment plant system. (Elefsiniotis and Li 2006; Min et al. 2002, Dąbrowski et al. 2010, Janczukowicz et al. 2011, 2013). This has become a premise for exploring other, alternative sources of organic carbon.

Molasses is a waste product that has a high potential as an external source of carbon. It is created as a by-product of the sugar industry 
and often used in the distillery industry. Molasses is a malleable liquid with a brown colour. The substance has a specific smell and a bittersweet taste. Molasses contains about $48-50 \%$ sucrose (Arshad et al. 2008, Silva et al. 2009, Smyk and Ignatowicz 2017). Molasses or hydrolysed molasses can be used to support biological wastewater treatment processes. The main component of molasses, i.e. polysaccharides, contains long chains that prevent rapid use of this substrate by denitrifying bacteria; therefore, it is recommended that molasses be hydrolysed to convert it into simpler compounds such as sucrose, fructose and glucose (Janczukowicz and Rodziewicz 2013). The difficulty in using molasses as ECS is its high density, which can create problems with the precise dosing of the substance (Arshad et al. 2008, Mąkinia and Czerwionka 2013, Silva et al. 2009).

The aim of the research was to determine the effect of molasses on the speed and efficiency of the denitrification process as well as the changes in COD fractions during individual wastewater treatment phases.

\section{MATERIALS AND METHODS}

The tests were performed during municipal wastewater treatment processes carried out in two independent reactors (R1 and R2) with SBR-type activated sludge (Smyk and Ignatowicz 2017). Their active volume was $13 \mathrm{dm}^{3}$, whereof $8 \mathrm{dm}^{3}$ was occupied by activated sludge, and the remaining volume was occupied by mechanically treated raw wastewater delivered from the Białystok wastewater treatment plant. Table 1 shows the operating parameters of the SBR reactors.

A single operating cycle of a reactor lasted 6 hours and comprised the following stages: wastewater supply ( $2 \mathrm{~min}$.), anaerobic mixing (60 minute), aeration (210 $\mathrm{min})$, sedimentation (60 min) and decantation (30 min). During the stage of aeration performed via a diffuser located at the reactor bottom, compressed air was supplied, depending on the operation stage, in amounts from 0.1 up to $2.0 \mathrm{mg} \mathrm{O} / \mathrm{dm}^{3}$; activated sludge concentration was $3.5 \mathrm{~kg} / \mathrm{m}^{3}$, sludge index fluctuated from 120 to $180 \mathrm{~cm}^{3} / \mathrm{g}$, chamber hydraulic load was $1.5 \mathrm{~m}^{3} / \mathrm{m}^{3} \cdot \mathrm{d}$ and the load of organic compounds was $0.2 \mathrm{~kg} \mathrm{COD} / \mathrm{m}^{3} \cdot \mathrm{d}$. Molasses were added to one of the SBRs 20 minutes after filling the wastewater. The dose of molasses was individually calculated taking into account the amount and composition of raw wastewater, assuming the COD/N ratio of 6 .

The wastewater samples were filtered, and each of the following parameters were determine individually, in accordance with the applicable methodology (Smyk and Ignatowicz 2017, Ignatowicz 2008, Puchlik et al. 2015):

- COD - dichromate method as per PN74/C-04578.03 standard,

- $\mathrm{BOD}_{5}$ - manometric method based on OxiTop standard,

- $\mathrm{N}_{-} \mathrm{NH}_{4}$ - spectrophotometric method as per PN-ISO 7150-1:2002 standard,

- $\mathrm{N}_{-} \mathrm{NO}_{3}$ - spectrophotometric method as per $\mathrm{PN}-82 / \mathrm{C}-04576 / 08$ standard,

- $\mathrm{N}_{\text {tot }}$ - spectrophotometric method as per PN-EN ISO 6878:2006 standard,

- $\mathrm{P}_{\text {tot }}$ - spectrophotometric method as per PN-C-04576-00:1973P standard.

COD fractions: $\mathrm{S}_{\mathrm{S}}$ (dissolved easily biodegradable), $\mathrm{S}_{\mathrm{I}}$ (dissolved non-degradable biologically), $X_{S}$ (organic suspension slowly degradable), $X_{I}$ (organic suspension non-degradable biologically) were determined based on ATV-A 131 guidelines (Dulekgurgen et al. 2006, Myszograj et al. 2017, Sadecka et al. 2011, Struk-Sokołowska, 2011, Wu et al. 2014).

The rate of NUR denitrification was determined using the formula:

$$
N U R=\frac{S_{N-N O 3, t 1}-S_{N-N O 3, t 2}}{\Delta t}\left[\frac{m g N-N O_{3}}{d m^{3} \cdot h}\right]
$$

where: $S_{N-N 03, t}-$ concentration of nitrate nitrogen at time of $\mathrm{t}\left[\mathrm{mgN} / \mathrm{dm}^{3}\right]$, $\Delta t$ - measurement time $[\mathrm{h}]$,

Table 1. Operating parameters of the SBR reactors

\begin{tabular}{|c|c|c|c|}
\hline Pos. & Indicator & Value & Unit of measure \\
\hline 1 & Activate sludge concentration & 3.5 & $\mathrm{~kg} / \mathrm{m}^{3}$ \\
\hline 2 & Load of organic compounds & $0.2 \div 0.3$ & $\mathrm{~kg} \mathrm{COD} / \mathrm{m}^{3} \cdot \mathrm{d}$ \\
\hline 3 & Sludge index & $120 \div 180$ & $\mathrm{~cm}^{3} / \mathrm{g}$ \\
\hline 4 & Chamber hydraulic load & 1.5 & $\mathrm{~m}^{3} / \mathrm{m}^{3} \cdot \mathrm{d}$ \\
\hline 5 & Decantation coefficient & 0.3 & - \\
\hline
\end{tabular}




\section{RESULTS AND DISCUSSION}

The obtained results are shown in Figures 1-5. According to the guidelines of ATV, Henze, Tora (2011), Yang (2012) and other authors, denitrification takes place without any disturbances if the $\mathrm{COD} / \mathrm{N}$ ratio is between 5 and 10 . The $\mathrm{COD} / \mathrm{N}$ ratio in the wastewater of the SBR reactors tested was insufficient for the denitrification process and was lower than the recommended range. The $\mathrm{COD} / \mathrm{N}$ ratio in the raw wastewater was 7.2 , while the reactors were filled with wastewater and the 20-minute mixing process reduced this value to 4.2. Adding molasses to the reactor increased the $\mathrm{COD} / \mathrm{N}$ ratio to the required value (Figure 1).

The amount of organic compounds defined as COD in the mechanically treated wastewater was $535 \mathrm{mgO}_{2} / \mathrm{dm}^{3}$ and $\mathrm{BOD}_{5} 300 \mathrm{mgO} / \mathrm{dm}^{3}$ (Figure 2). The concentration of $\mathrm{N}_{\text {tot }}$ in raw wastewater was $73.9 \mathrm{mgN} / \mathrm{dm}^{3}$, ammonium nitrogen $-51.1 \mathrm{mgN} / \mathrm{dm}^{3}$ and nitrates $-2.6 \mathrm{mgN} / \mathrm{dm}^{3}$ (Figure 3 decrease in the amount of organic matter was noted 20 minutes after the SBRs were filled, which indicates that the assimilable carbon compounds were absorbed by the denitrifying bacteria. The amount of organic compounds measured as COD in the control reactor was $268 \mathrm{mgO} / \mathrm{dm}^{3}$ and $\mathrm{BOD}_{5} 130 \mathrm{mgO}_{2} / \mathrm{dm}^{3}$. Similar values were recorded in the second $\mathrm{R} 2$ reactor: $\mathrm{COD}$ was $259 \mathrm{mgO} / \mathrm{dm}^{3}$ and $\mathrm{BOD}_{5} 130 \mathrm{mgO} / \mathrm{dm}^{3}$. The concentration of ammonium nitrogen in R1 was $44.9 \mathrm{mgN} / \mathrm{dm}^{3}$ and $45.8 \mathrm{mgN} / \mathrm{dm}^{3}$ in R2. The concentration of nitrates increased slightly, in SBR $\mathrm{R} 1$ the concentration was $3.9 \mathrm{mgN} / \mathrm{dm}^{3}$, whereas in SBR R2 - $4.0 \mathrm{mgN} / \mathrm{dm}^{3}$.

Molasses were then added to SBR R2 and after twenty minutes of anaerobic denitrification, further samples were taken. In the control SBR, where the wastewater treatment process was carried out without the assistance of ECS, a further slight decrease in the amount of organic compounds defined as $\mathrm{COD}\left(262 \mathrm{mgO}_{2} / \mathrm{dm}^{3}\right)$ and BOD $_{5}\left(120 \mathrm{mgO}_{2} / \mathrm{dm}^{3}\right)$ was observed (Figure 2). The introduction of ECS in the form of molasses caused an increase in the COD values in SBR $\mathrm{R} 2$ to $281 \mathrm{mgO}_{2} / \mathrm{dm}^{3}$. The concentration of $\mathrm{N}_{\text {tot }}$ in SBR R1 decreased to $55.9 \mathrm{mgN} / \mathrm{dm}^{3}$ (Figure 3). InSBR R2, the concentration of $\mathrm{N}_{\text {tot }}$ also decreased to $54.0 \mathrm{mgN} / \mathrm{dm}^{3}$. In the case of nitrates, a lower concentration was recorded in $\mathrm{R} 1$ than in the SBR with added molasses - the concentration in R1 was $2.4 \mathrm{mgN} / \mathrm{dm}^{3}$, while the concentration in $\mathrm{R} 2$ was $2.9 \mathrm{mgN} / \mathrm{dm}^{3}$. The concentration of ammonium nitrogen decreased slightly in the reactor R1 to $43.2 \mathrm{mgN} / \mathrm{dm}^{3}$. In SBR R2, a high decrease in ammonium nitrogen concentration to $41.0 \mathrm{mgN} / \mathrm{dm}^{3}$ was recorded.

After another twenty minutes of anaerobic wastewater treatment, a further decrease in COD $\left(259 \mathrm{mgO}_{2} / \mathrm{dm}^{3}\right)$ was observed in the $\mathrm{R} 1$ and $\mathrm{BOD}_{5}$ reactors $\left(115 \mathrm{mgO}_{2} / \mathrm{dm}^{3}\right)$. COD was also reduced to $273 \mathrm{mgO}_{2} / \mathrm{dm}^{3}$ and $\mathrm{BOD}_{5}$ to $115 \mathrm{mgO} / \mathrm{dm}^{3}$ in the reactor with molasses (Figure 2). A clear difference in nitrogen form concentrations between the reactors was observed. The concentration of $\mathrm{N}_{\text {tot }}$ continued to decrease in SBR R1 and was $53.6 \mathrm{mgN} / \mathrm{dm}^{3}$. In the case of SBR R2, the concentration of $\mathrm{N}_{\text {tot }}$ was $43.3 \mathrm{mgN} / \mathrm{dm}^{3}$ (Figure 3).

The COD value in the wastewater treated from the $\mathrm{R} 1$ reactor after decantation was $37 \mathrm{mgO} / \mathrm{dm}^{3}$, while $\mathrm{BOD}_{5}$ was $9 \mathrm{mgO} / \mathrm{dm}^{3}$ (Figure 2). Despite the addition of ECS in the wastewater treated with molasses, COD was $25 \mathrm{mgO} / \mathrm{dm}^{3}$ and $\mathrm{BOD}_{5} 4.0 \mathrm{mgO} / \mathrm{dm}^{3}$. These values are lower than in SBR R1, where no additional ECS was used. The concentration of $\mathrm{N}_{\text {tot }}$ in the wastewater treated from SBR R1 was $14.8 \mathrm{mgN} / \mathrm{dm}^{3}$, ammonium nitrogen $-2.1 \mathrm{mgN} / \mathrm{dm}^{3}$ and nitrates $8.8 \mathrm{mgN} / \mathrm{dm}^{3}$ (Figure 3). In SBR R1, the removal of $\mathrm{N}_{\text {tot }}$ took place with an efficiency of $80 \%$ and ammonium nitrogen - of $95.9 \%$. In the case of SBR R2, the concentration of $\mathrm{N}_{\text {tot }}$ in treated

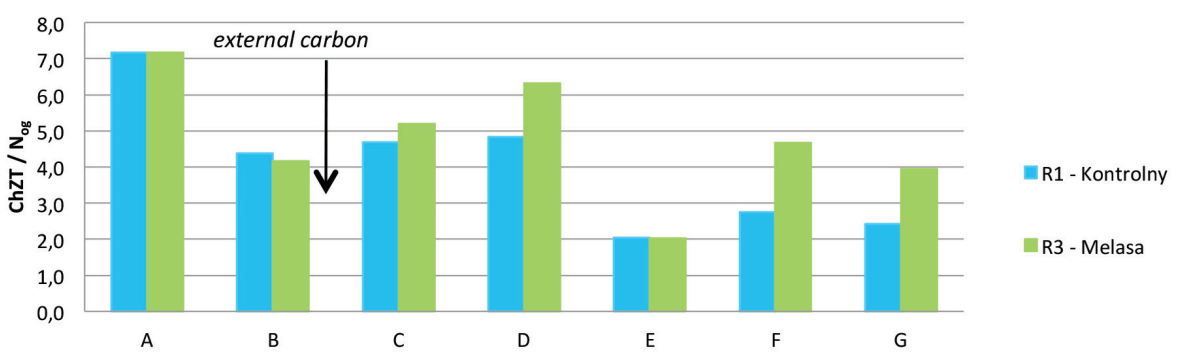

Figure 1. Comparison of COD to $\mathrm{N}_{\text {tot }}$ at control points (A - raw wastewater; $\mathrm{B}$ - wastewater after filling (20 min); $\mathrm{C}$ - denitrification process ( $20 \mathrm{~min})$; $\mathrm{D}$ - denitrification process (20 min); $\mathrm{E}$-nitrification process (90 min); F - nitrification process (120 min); $\mathrm{G}$ - decantation (30 min)) 


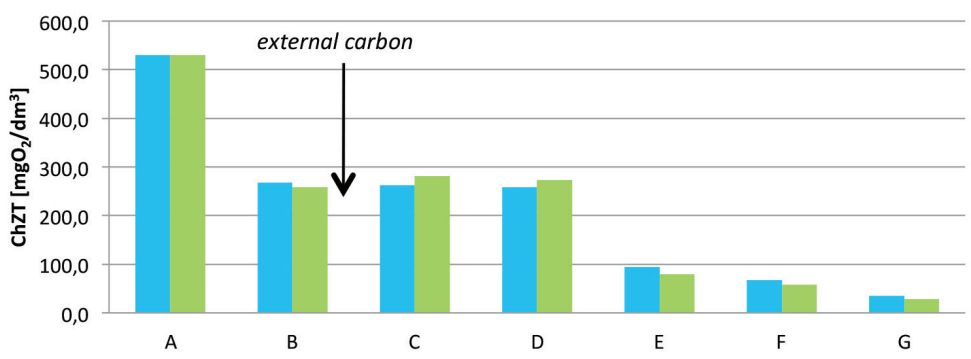

- R1 - Kontrolny

R3 - Melasa

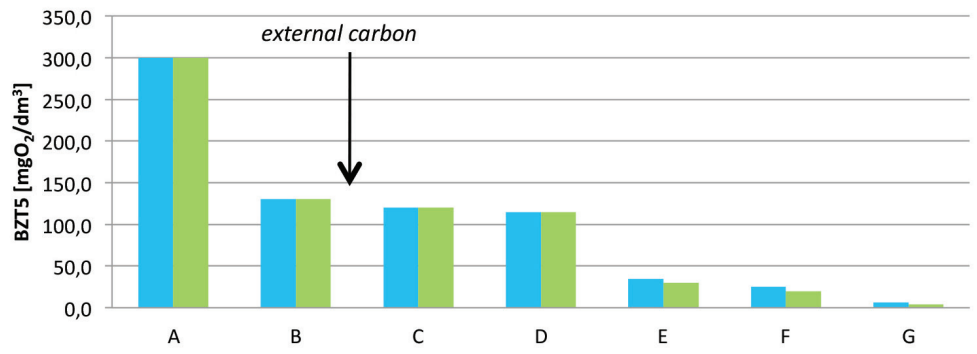

R1 - Kontrolny

- R3 - Melasa

Figure 2. Changes in the amount of organic compounds during the wastewater treatment process

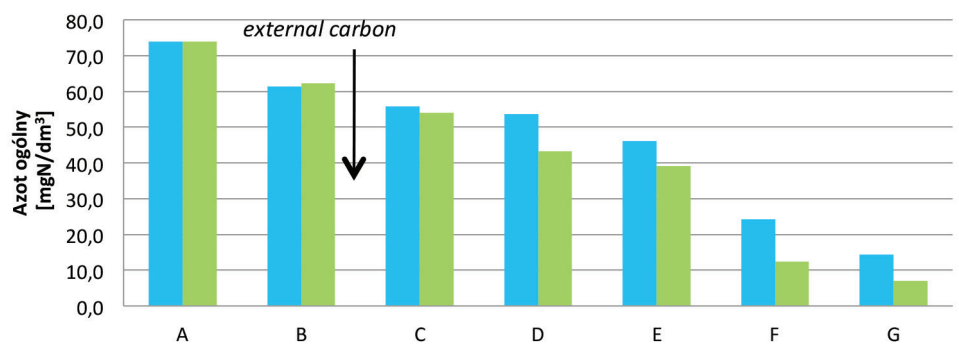

M1 - Kontrolny

- R3 - Melasa

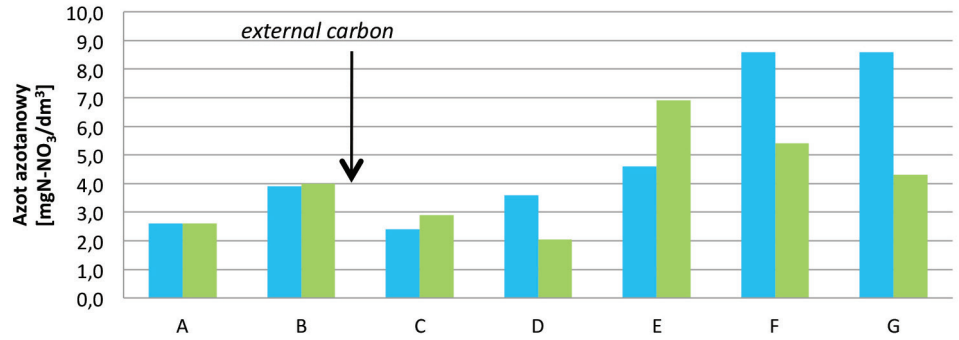

R1 - Kontrolny

R3 - Melasa

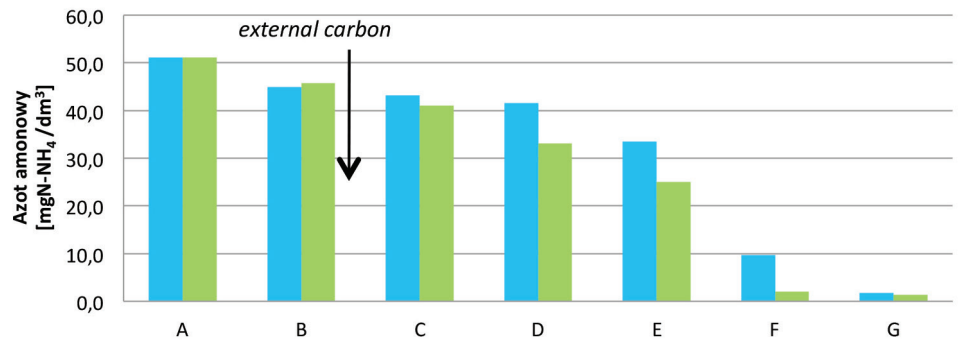

R1 - Kontrolny

- R3 - Melasa

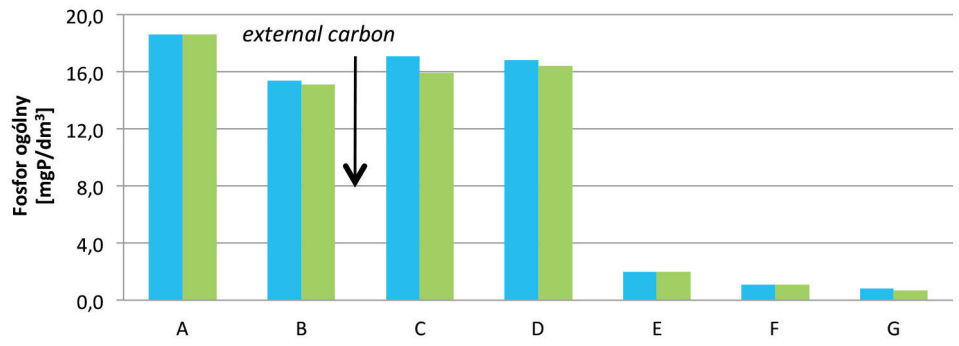

- R1 - Kontrolny

M3 - Melasa

Figure 3. Changes in the concentration of nitrogen and phosphorus compounds during the wastewater treatment processes 
wastewater was $7.2 \mathrm{mgN} / \mathrm{dm}^{3}$, ammoniacal nitrogen $-1.4 \mathrm{mgN} / \mathrm{dm}^{3}$ and nitrates $-3.9 \mathrm{mgN} / \mathrm{dm}^{3}$. In SBR R2, the removal of $\mathrm{N}_{\text {tot }}$ occurred with an efficiency of $90.3 \%$ and ammoniacal nitrogen of $97.3 \%$. The use of molasses resulted in a higher efficiency of the wastewater treatment process and, above all, in a more effective removal of nitrogen compounds.

During the study, the COD fractions in the wastewater were determined in order to determine their quantitative and percentage share. Determination of the COD fraction allows the assessment of the susceptibility of wastewater to biological treatment, additionally indicating the pollutants which are difficult to decompose and reduce the effectiveness of biological wastewater treatment. A distinction is made between easily biodegradable, hardly biodegradable and non-biodegradable compounds. The biodegradable fraction includes the fraction of dissolved organic substances easily biodegradable $\mathrm{S}_{\mathrm{S}}$ and the fraction of insoluble organic substances slowly biodegradable $\mathrm{X}_{\mathrm{S}}$. The non-biodegradable fraction includes fractions of dissolved non-biodegradable organic substances $\mathrm{S}_{\mathrm{I}}$ and insoluble non-biodegradable organic substances $X_{\mathrm{I}}$ (Sadecka et al. 2011, Myszograj 2017, Dulekgurgen et al. 2006, Wu et al. 2014).

Figure 4 shows the quantitative share of the individual fractions in individual reactors. The fraction of insoluble, slowly biodegradable $\mathrm{X}_{\mathrm{S}}$ organic compounds dominated in the mechanically treated raw municipal wastewater. This fraction accounted, on average, for $46.6 \%$ of the total COD of wastewater. The percentage share of the fraction of dissolved organic compounds easily biodegradable $\mathrm{S}_{\mathrm{S}}$ in raw municipal wastewater was $33.8 \%$ on average. The fraction of insoluble non-biodegradable organic compounds $X_{I}$ accounted for $15.5 \%$ of the total COD of wastewater. The fraction of dissolved non-biodegradable organic compounds $\mathrm{S}_{\mathrm{I}}$ had the lowest percentage share in raw municipal wastewater $-4.1 \%$.

After filling the SBRswith wastewater and mixing for twenty minutes, a decrease in the fraction of insoluble organic compounds slowly biodegradable $\mathrm{X}_{\mathrm{S}}$ was observed by $202.5 \mathrm{mgO}_{2} / \mathrm{dm}^{3}$ on average. A decrease in the fraction of easily biodegradable organic compounds $\mathrm{S}_{\mathrm{S}}$ was also observed from the mean value of $211.0 \mathrm{mgO} / \mathrm{dm}^{3}$ to 132 in the control reactor and to $136 \mathrm{mgO}_{2} / \mathrm{dm}^{3}$ in the reactor with molasses. The percentage shares of the $\mathrm{S}_{\mathrm{S}}$ fractions increased to $49.64 \%$ for $\mathrm{R} 1$ and $52.20 \%$ for R2. The value of the fractions of insoluble non-biodegradable organic compounds $\mathrm{X}_{\mathrm{I}}$ also decreased, on average, by $67.5 \mathrm{mgO} / \mathrm{dm}^{3}$, which in both reactors accounted for about $10 \%$ of the total COD of wastewater. The fraction of dissolved non-biodegradable organic compounds $\mathrm{S}_{\mathrm{I}}$ did not change its value as a result of filling the SBRs, while its percentage share increased slightly and ranged from 5.0 to $7.9 \%$.

Molasses was added to the R2 reactor. After twenty minutes of wastewater mixing in the reactors with added molasses, an increase in the amount of dissolved, easily biodegradable organic compounds determined by the SS fraction was noted at $9.0 \mathrm{mgO}_{2} / \mathrm{dm}^{3}$. In the control reactor, a decrease in the value of readily biodegradable organic compounds fraction at $3.0 \mathrm{mgO}_{2} / \mathrm{dm}^{3}$ was recorded. In both SBRs, a decrease in the value of $X_{S}$ and $X_{S}$ fractions of insoluble, slowly biodegradable organic compounds and in the value of non-biodegradable, non-biodegradable organic compounds $\mathrm{X}_{\mathrm{I}}$ fractions was recorded, which is caused by the combination of the $\mathrm{X}_{\mathrm{I}}$ fraction with activated sludge flocculation.

The increased amount of easily assimilable carbon compounds has contributed to an increase in the denitrification rate. Figure 5 shows the average denitrification rate of NUR. In the case of the denitrification rate in a SBR without addition of ECS, the speed was much lower and amounted to only $0.45 \mathrm{mgN} \cdot \mathrm{dm}^{3} / \mathrm{h}$, while the difference in rate between the SBRs was $2.48 \mathrm{mgN} \cdot \mathrm{dm}^{3} / \mathrm{h}$.

\section{CONCLUSIONS}

1. The application of molasses as ECS in wastewater treatment increased the effectiveness of removing the forms of nitrogen while maintaining a high efficiency of removing organic compounds.

2. The use of molasses reduced the nitrate concentration in the treated wastewater by $4.9 \mathrm{mgN} / \mathrm{dm}^{3}$ compared to the SBR without ECS support.

3. The introduction of molasses into municipal wastewater resulted in an increase of $10 \%$ of the dissolved, easily biodegradable organic compounds called SS fraction in the $\mathrm{R} 2$ reactor.

4. Molasses, as a waste product, can be successfully used as an external source of carbon in denitrification processes. 


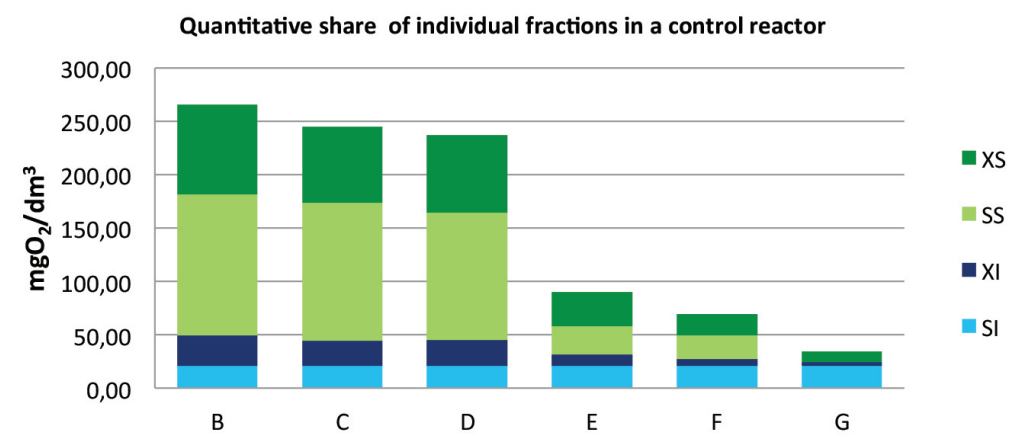

Quantitative share of individual fractions in a reactor with molasses

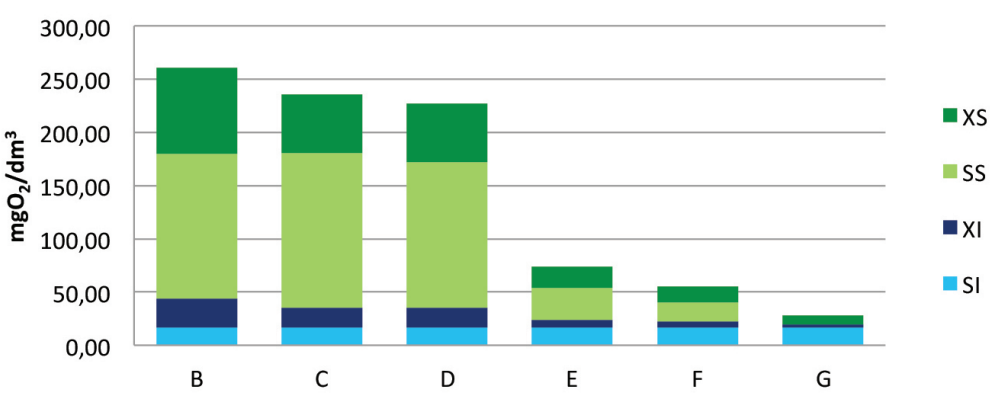

Percentage of individual fractions in a control reactor

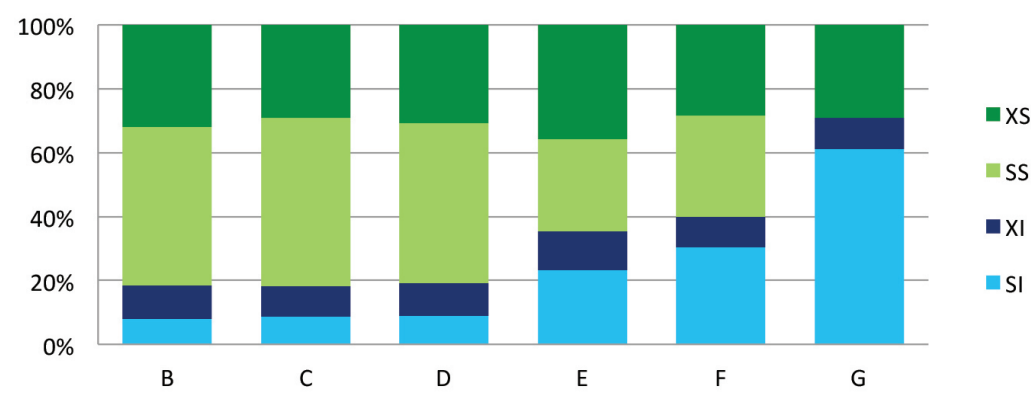

Percentage of individual fractions in a reactor with molasses

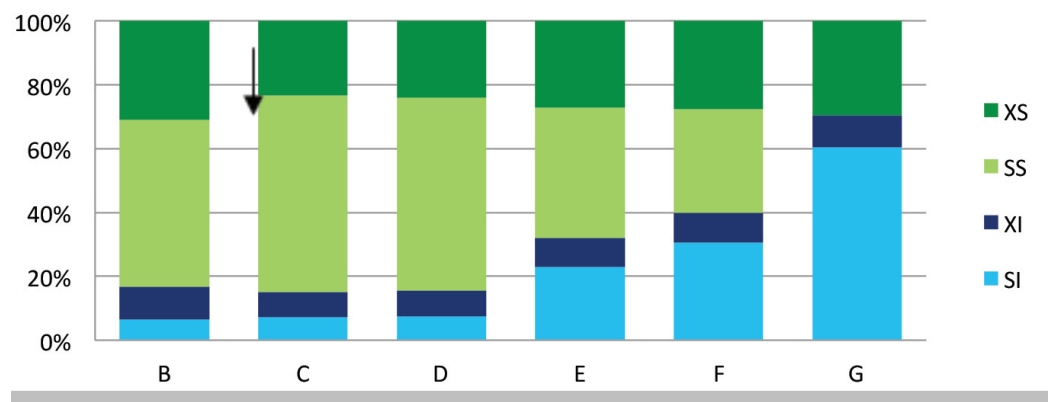

Fig. 4. Quantitative share and percentage of individual fractions in a reactor without the addition of a carbon source (R1) and a reactor with the addition of molasses (R2) (B - wastewater after filling (20 min); $\mathrm{C}$ - denitrification process ( $20 \mathrm{~min}) ; \mathrm{D}$ - denitrification process (20 $\mathrm{min})$; $\mathrm{E}$ - nitrification process $(90 \mathrm{~min})$; $\mathrm{F}$ - nitrification process (120 min); $\mathrm{G}$ - decantation (30 min).

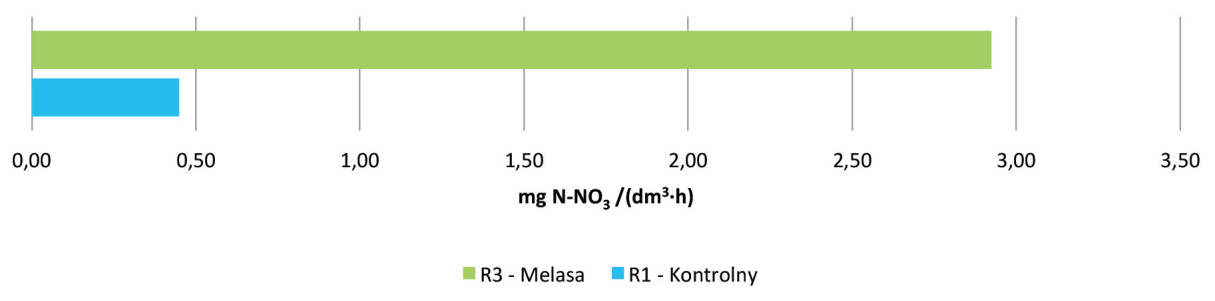

Fig. 5. The denitrification rate comparison 


\section{Acknowledgements}

The research was funded by Research Project conducted in the Department of Technology in Engineering and Environmental Protection (WZ/WBiIS/ 8/2019).

\section{REFERENCES}

1. Arshad M., Chan Z.M., Khalil-ur-Rehman M., Szach F.A., Rajoka M.I. 2008. Optimization of process variables for minimization of byproduct formation during fermentation of blackstrap molasses to ethanol at industrial scale. Lett. Appl. Microbiol., 47(5), 410-414

2. Bernat K., Kulikowska D., Kordel A. 2016. Usuwanie związków azotu ze ścieków w procesach denitryfikacji i skróconej denitryfikacji z wykorzystaniem melasy jako źródła węgla organicznego. Ochrona Środowiska, 38(2), 9-15

3. Cherchi C., Onnis-Hayden A., El-Shawabkeh I., Gu A.Z. 2009. Implication of using different carbon sources for denitrification in wastewater treatments. Water Environment Research, 81(8), 788-799

4. Dąbrowski W., Puchlik M. 2010. Udział frakcji ChZT w ściekach mleczarskich w oczyszczalni stosującej intensywne usuwanie związków węgla, azotu i fosforu. Rocznik Ochrona Środowiska, 12, 735-746

5. Dulekgurgen E., Dogruel S., Karahan Ö., Orhon D. 2006. Size distribution of wastewater COD fractions as an index for biodegradability. Water Research, 40, 273-282.

6. Elefsiniotis, P., Li, D. 2006. The effect of temperature and carbon source on denitrification using volatile fatty acids. Biochemical Engineering Journal, 28(2), 148-155.

7. Fernández-Nava, Y., Maranón, E., Soons, J., Castrillón, L. 2010. Denitrification of high nitrate concentration wastewater using alternative carbon sources. Journal of Hazardous Materials, 173, 682-688.

8. Ignatowicz K.; Piekarski J. Kozlowski D. 2011. Intensification of the Denitrification Process by Using Brenntaplus VP1 Preparation, Rocznik Ochrona Srodowiska Vol. 17, p 1178-1195 Part: 2

9. Ignatowicz K. 2008. Sorption process for migration reduction of pesticides from graveyards|. Archives of Environmental Protection. 34(3). 143-149.

10. Janczukowicz W., Rodziewicz J., Filipkowska U. 2011. Ocena procesów biologicznego usuwania azotanów (V) i fosforanów w komorze SBR z zewnętrznym źródłem węgla. Rocznik Ochrona Środowiska, 13, 453-470

11. Janczukowicz, W., Rodziewicz, J. 2013. Źródła węgla w procesach biologicznego usuwania związków azotu i fosforu, Monografie Komitetu Inżynierii Środowiska Polskiej Akademii Nauk, vol. 114, Lublin.

12. Mąkinia, J., Czerwonka, K. 2013. Wytyczne oceny alternatywnych źródeł węgla. Innowacyjne źródło węgla dla wspomagania denitryfikacji w komunalnych oczyszczalniach ścieków. Projekt współfinansowany ze środków Europejskiego Funduszu Rozwoju Regionalnego w ramach Programu Operacyjnego Innowacyjna Gospodarka.

13. Min, K., Park, K.-S., Jung, Y.-J., Khan, A.R. 2002. Acidogenic Fermentation: Utilization of Wasted Sludge as a Carbon Source in the Denitrification Process. Environmental Technology, 23(3), 293-302.

14. Myszograj, S., Płuciennik-Koropczuk, E., Jakubaszek, A., Świętek, A. 2017. COD fractions - methods of measurement and use in wastewater treatment technology. Civil And Environmental Engineering Reports, 24(1), 195-206.

15. Puchlik M., Ignatowicz K., Dabrowski W. 2015. Influence of bio- preparation on wastewater purification process in constructed wetlands. Journal of Ecological Engineering, 16 (1). 159-163.

16. Sadecka, Z., Płuciennik-Koropczuk, E., Sieciechowicz, A. 2011. Frakcje ChZT ścieków w modelach biokinetycznych. Forum Eksploatatora, 54(3), 72-77.

17. Silva F., Nadais H., Prates A., Arroja L., Capela I. 2009. Molasses as an external carbon source for anaerobic treatment of sulphite evaporator condensate. Bioresource Technology, 100, 1943-1950.

18. Smyk J., Ignatowicz K. 2017. The influence of molasses on nitrogen removal in wastewater treatment with activated sludge, Journal of Ecological Engineering, 18, 199-203.

19. Struk-Sokołowska J. 2011. Zmiany udziału frakcji ChZT podczas oczyszczania ścieków komunalnych z dużym udziałem ścieków mleczarskich. Rocznik Ochrony Środowiska, 13, 2015-2032.

20. Torà, J.A., Baeza, J.A., Carrera, J., Oleszkiewicz, J.A. 2011. Denitritation of a high-strength nitrite wastewater in a sequencing batch reactor using different organic carbon sources. Chemical Engineering Journal, 172 (2-3), 994-998.

21. Wu J., Yan G., Zhou G., Xu T. 2014. Wastewater COD biodegradability fractionated by simple physical - chemical analysis. Chemical Engineering Journal, 258, 450-459.

22. Yang X., Wang S., Zhou L. 2012. Effect of carbon source, $\mathrm{C} / \mathrm{N}$ ratio, nitrate and dissolved oxygen concentration on nitrite and ammonium production from denitrification process by Pseudomonas stutzeri D6. Bioresource Technology, 104, 65-72. 